\title{
Physiological stress during cardiovascular magnetic resonance - handgrip exercise induced hemodynamic effects
}

\author{
Florian von Knobelsdorff-Brenkenhoff ${ }^{1,4^{*}}$, Matthias A Dieringer ${ }^{1,4}$, Katharina Fuchs ${ }^{2}$, Fabian Hezel ${ }^{2}$, \\ Wolfgang Renz $z^{2,3}$, Thoralf Niendorf ${ }^{2}$, Jeanette Schulz-Menger ${ }^{1,4}$
}

From 15th Annual SCMR Scientific Sessions

Orlando, FL, USA. 2-5 February 2012

\section{Background}

Pharmacological stress during cardiovascular magnetic resonance imaging (CMR) is limited by its non-physiological character and the risk of adverse events, whereas physical stress using bicycle exercise is challenging due to patients' motion. This study tested the feasibility of handgrip exercise as an alternative and assessed its hemodynamic effects in volunteers.

\section{Methods}

Twenty-nine volunteers (17 males, mean age 36 \pm 12 years) underwent isometric handgrip stress testing using a CMR-compatible system (Sensory-Motor Systems Lab, Zurich, Switzerland) at 1/3 of the maximal voluntary contraction in a 3T scanner (Verio, Siemens, Germany). The actual force was presented to the volunteers on a screen via a mirror system to enable self-control. In all subjects, heart rate by electrocardiographic monitoring, and blood pressure (BP) by an arm cuff sphygmomanometer were repeatedly measured. The double product (heart rate $\mathrm{x}$ mean arterial BP) was used as an indicator of cardiac work. Left ventricular chamber quantification was done at baseline using steady-state free-precession cine imaging. In 11 volunteers, phasecontrast acquisitions were performed at the sinutubular level at rest and every minute of sustained handgrip exercise to quantify cardiac output.

\section{Results}

Maximal voluntary contraction was $264 \pm 94$ N. Mean exercise duration was $7 \pm 2 \mathrm{~min}$. All flow measurements during exercise provided diagnostic image quality without motion artifacts. Heart rate, BP, stroke volume and double product increased in all subjects between rest and peak exercise (apart from $\mathrm{n}=1$ with mildly decreasing BP). On average, heart rate increased from $65 \pm 3$ to $80 \pm 14 / \mathrm{min}$, systolic BP from $122 \pm 12$ to $138 \pm 13 \mathrm{mmHg}$, diastolic BP from $68 \pm 10$ to $79 \pm 10 \mathrm{mmHg}$, mean BP from $86 \pm 9$ to $99 \pm 10 \mathrm{mmHg}$, double product from $5487 \pm 1487$ to $7763 \pm 1607 \mathrm{mmHg} / \mathrm{min}$ and cardiac output from 5.4 \pm 0.8 to $7.4 \pm 1.11 / \mathrm{min}$ (each $\mathrm{p}<0.001$ ). Apart from males exhibiting a stronger increase of systolic BP compared to women $(21 \pm 16$ vs. $8 \pm 6 \mathrm{mmHg} ; \mathrm{p}=0.02)$, all other changes were independent of sex, age, left ventricular ejection fraction, enddiastolic volume index and mass index, as well as absolute handgrip force.

\section{Conclusions}

Handgrip exercise testing during CMR is feasible and leads to considerable hemodynamic changes in healthy volunteers.

\section{Funding}

The examinations were in part supported by the Else Kröner Fresenius Stiftung.

\section{Author details \\ 'Working Group Cardiovascular MRI, Charite Medical University, Berlin, Germany. ${ }^{2}$ Berlin Ultrahigh Field Facility, Max-Delbrueck-Center, Berlin, Germany. ${ }^{3}$ Siemens Healthcare Sector, Erlangen, Germany. ${ }^{4}$ Cardiology and Nephrology, HELIOS Klinikum Buch, Berlin, Germany.}

Published: 1 February 2012

'Working Group Cardiovascular MRI, Charite Medical University, Berlin,

Germany

Full list of author information is available at the end of the article

(c) 2012 von Knobelsdorff-Brenkenhoff et al; licensee BioMed Central Ltd. This is an open access article distributed under the terms of the Creative Commons Attribution License (http://creativecommons.org/licenses/by/2.0), which permits unrestricted use, distribution, and reproduction in any medium, provided the original work is properly cited. 
doi:10.1186/1532-429X-14-S1-P229

Cite this article as: von Knobelsdorff-Brenkenhoff et al:: Physiological stress during cardiovascular magnetic resonance - handgrip exercise induced hemodynamic effects. Journal of Cardiovascular Magnetic

Resonance 2012 14(Suppl 1):P229.

Submit your next manuscript to BioMed Central and take full advantage of:

- Convenient online submission

- Thorough peer review

- No space constraints or color figure charges

- Immediate publication on acceptance

- Inclusion in PubMed, CAS, Scopus and Google Scholar

- Research which is freely available for redistribution

Submit your manuscript at www.biomedcentral.com/submit

() BioMed Central 